\title{
Use of a lactic acid plus lactoserum intimate liquid soap for external hygiene in the prevention of bacterial vaginosis recurrence after metronidazole oral treatment
}

\author{
M. Valeria Bahamondes ${ }^{1}$, Priscila Mendes Portugal ${ }^{1}$, Eliane Melo Brolazo ${ }^{1}$, José Antônio Simões ${ }^{1}$, Luis Bahamondes ${ }^{1}$ \\ ${ }^{1}$ Human Reproduction Unit, Department of Obstetrics and Gynecology, Medical School, Universidade Estadual de Campinas (UNICAMP) and National Institute of Hormones and \\ Women Health, Campinas, SP, Brazil
}

Study conducted at Human Reproduction Unit, Department of Obstetrics and Gynecology, Medical School, Universidade Estadual de Campinas (UNICAMP) and National Institute of Hormones and Women Health, Campinas, SP, Brazil

Submitted on: 10/21/2010 Approved on: 04/12/2011

Financial Support: This study was financed by an unrestricted grant by Sanofi-aventis

Correspondence to: Luis Bahamondes Caixa Postal 6181

Campinas, SP, Brazil CEP: $13084-971$

Phone: (19) 3289-2856

Fax: (19) 3289-2440 bahamond@caism.unicamp.br

Conflict of interest: None.

Cᄋ2011 Elsevier Editora Ltda. Todos os direitos reservados.

\section{SUMMARY}

Objective: To determine the recurrence of bacterial vaginosis (BV) after the use of a lactic acid plus lactoserum liquid soap starting immediately after the treatment with oral metronidazole and the quality of life of the participants. Methods: A total of 123 women with diagnosis of BV with at least three of the following criteria: 1) homogeneous vaginal discharge without inflammation of the vagina or vulva; 2 ) vaginal $\mathrm{pH}>4.5 ; 3$ ) positive Whiff test; and 4) "clue cells" in more than $20 \%$ of the epithelial cells in the vagina. A Nugent score $>4$ in the vaginal bacterioscopy was also used. After BV diagnosis, metronidazole $500 \mathrm{mg}$ was administered orally bid during 7 days. Patients cured of BV were then instructed to use 7.5 to $10 \mathrm{~mL}$ of a lactic acid plus lactoserum liquid soap once-a-day for hygiene of the external genital region. Three subsequent control visits after starting the hygiene treatment $(30,60$, and 90 days; \pm 5 days) were scheduled. A questionnaire was applied in the form of visual analogue scale (VAS) in all the visits regarding: 1) level of comfort at the genital region; 2) malodorous external genitalia; 3) comfort in sexual intercourse; 4) satisfaction with intimate hygiene; and 5) self-esteem. Results: Ninety two (74.8\%) women initiated the use of a lactic acid plus lactoserum liquid soap at visit 1 . At visit 2, 3, and 4 there were 84,62 and 42 women available for evaluation, respectively. The rate of recurrence of BV was $19.0 \%, 24.2 \%$ and $7.1 \%$, respectively in the three visits and vaginal candidiasis was observed in five treated women. Quality of life was evaluated in the 42 women who completed the four visits schedule and there were significant improvement in the five domains assessed. Conclusion: A lactic acid plus lactoserum liquid soap for external intimate hygiene may be an option for the prevention of BV recurrence after treatment and cure with oral metronidazole.

Keywords: Bacterial vaginosis; lactic acid, treatment; recurrence.

\section{RESUMO}

\section{Uso do ácido láctico com lactoserum em sabonete líquido íntimo para higiene externa na prevenção da recorrência de vaginose bacteriana após tratamento oral com metronidazol}

Objetivo: Determinar a ocorrência de vaginose bacteriana (VB) após o uso de acido láctico com lactoserum em sabonete líquido iniciado imediatamente após o tratamento com metronidazol oral e qualidade de vida das participantes. Métodos: Um total de 123 mulheres com dianóstico de VB com ao menos três dos seguintes critérios: 1) leucorreia vaginal homogênea sem inflamação de vagina ou vulva; 2 ) $\mathrm{pH}$ vaginal $>4,5$; 3 ) teste positivo de Whiff; e 4) "clue cells" em mais de $20 \%$ das células epiteliais na vagina. O escore de Nugent $>4$ na bacterioscopia vaginal também foi usado. Após o diagnóstico de VB, metronidazol 500 mg oral foi ministrado durante 7 dias. Pacientes curados da VB foram instruídos a usar 7,5 a $10 \mathrm{~mL}$ de acido láctico com lactoserum em sabonete líquido uma vez ao dia para higiene da genitália externa. Três visitas de controle foram agendadas (30, 60 e 90 dias; \pm 5 dias). Um questionário foi aplicado na forma de escala visual análoga (EVA) em todas as visitas sobre: 1) nível de conforto na região genital; 2) mau odor na genitália; 3) conforto na relação sexual; 4) satisfação com higiene íntima; e 5) autoestima. Resultados: Noventa e duas $(74,8 \%)$ mulheres iniciaram o uso de ácido láctico com lactoserum líquido na visita 1 . Na visita 2 , 3 e 4 foram 84, 62 e 42 mulheres para avaliação, respectivamente. A taxa de recorrência da VB foi $19,0 \%, 24,2 \%$ e $7,1 \%$, respectivamente nas três visitas e candidíase vaginal foi observada em cinco mulheres. Qualidade de vida foi avaliada em 42 mulheres que completaram as quatro visitas agendadas e houve uma melhora significativa nos cinco domínios avaliados. Conclusão: $\mathrm{O}$ uso de acido láctico com lactoserum em sabonete líquido para higiene externa intima pode ser uma opção para a prevenção da recorrência de VB após tratamento e cura com metronidazol oral.

Unitermos: Vaginose bacteriana; metronidazol; resultado de tratamento. 


\section{INTRODUCTION}

Bacterial vaginosis (BV) is the most common vaginitis among women of reproductive age. It affects 15$25 \%$ of patients with gynecological complaints and has a prevalence rate of $60 \%$ in women attended in sexual transmitted diseases (STDs) clinics ${ }^{1-3}$. BV is defined as a condition characterized by the replacement of the normal vaginal flora in which lactobacilli are predominant by proliferating anaerobic bacteria including Gardnerella vaginalis $(\mathrm{GV})$.

Metronidazole, administered by oral or vaginal route, is the drug of choice recommended for the treatment of BV by the US Center for Disease Controls (CDC) ${ }^{4}$. Treatment with metronidazol is associated with up to $80 \%$ remission after 7-10 days administration either through oral or vaginal route 5 . However, therapeutic failures and BV recurrence are observed in $30 \%$ and $70 \%$ of patients one month and three months after treatment, respectively ${ }^{6,7}$.

Failure to restore the normal vaginal flora is considered the main reason for $\mathrm{BV}$ recurrence after treatment with metronidazole. For this reason, acidification of the vaginal environment has been proposed as $\mathrm{BV}$ treatment, or as an alternative for recurrence prevention ${ }^{1,3}$. It has also been suggested that a vaginal $\mathrm{pH}$ higher than the physiological range (3.8 to 4.5 ) induces the growth and predominance of anaerobic bacteria which is the case of most patients diagnosed with $\mathrm{BV}^{8}$. In general, these bacteria are unable to grow at $\mathrm{pH}$ below $4.5^{9}$.

In one study with patients diagnosed with BV it was observed that lactobacilli were predominant in the control group whereas anaerobes were predominant in $\mathrm{BV}$ patients ${ }^{10}$. The use of intravaginal lactate-gel $(\mathrm{pH} 3.5$; $5 \mathrm{~mL}$ ) for 7 days was as effective as oral metronidazole (500 mg bid for 7 days). However, although anaerobes were significantly reduced, BV was not reduced.

A lactic acid plus lactoserum liquid soap (Dermacyd ${ }^{\oplus}$ Femina, Sanofi-aventis, Brazil) is available on the market as an acid liquid soap with lactic acid plus lactoserum with a $\mathrm{pH} \sim 4.0$ and is indicated for helping in the prevention of gynecological infections when used for external genitalia hygiene. The formulation contains a lactic acid plus lactoserum complex and could contribute to maintain a physiologic vulvovaginal $\mathrm{pH}$ although there is no evidence to that effect, neither that it prevents $\mathrm{BV}$ recurrence.

This study was designed to determine the recurrence rate of $\mathrm{BV}$ up to three months after treatment with a lactic acid plus lactoserum liquid soap. The treatment was started immediately after BV remission obtained with the standard treatment with oral metronidazole. The study objective was also to evaluate the rate of vulvovaginal candidiasis throughout the period of external hygiene procedure with a lactic acid plus lactoserum liquid soap as well as the patients' quality of life.

\section{Methods}

This open label non-comparative study was conducted at the Human Reproduction Unit, Department of Obstetrics and Gynecology, Universidade de Campinas (UNICAMP), Medical School, Campinas, Brazil. The project was approved by the Institutional Ethics Committee and all volunteers signed an informed consent prior to study inclusion. The study was conducted from September 2007 through December 2008. This study has been sponsored by Sanofi-aventis Brazil. The investigators were responsible for the study design and conduction, data management and statistical analysis, as well as for the manuscript preparation, with no interference from the sponsor.

\section{SUBJECTS}

Women were enrolled if they fulfilled the inclusion criteria as follows: age $<50$ years; clinically confirmed diagnosis of BV; vaginal fresh exam and Gram stain test negative for candidiasis and Trichomonas vaginalis. The exclusion criteria were: women with previous or current oral metronidazole therapeutic failure for $\mathrm{BV}$, genital herpes lesions or warts, pregnant women or those breastfeeding in the last three months prior to enrollment, history of any STDs in the last six months before enrollment, including human immunodeficiency virus infection, diabetes mellitus or other chronic disease, use of corticosteroids, chemotherapy, alcohol or drug abuse.

\section{DiAgnosis of BV}

The diagnostic tests included vaginal $\mathrm{pH}$ measurement, Whiff test and the collection of three vaginal swabs: one to perform a fresh exam with saline solution; one for a fresh exam with $\mathrm{KOH}$ and the third to perform a Gramstained bacterioscopy. The clinical diagnosis of BV was defined according to at least three of the following criteria: 1) homogeneous vaginal discharge without inflammation of the vagina or vulva; 2) vaginal $\mathrm{pH}>4.5 ; 3$ ) positive Whiff test; and 4) "clue cells" in more than $20 \%$ of the epithelial cells in a fresh vaginal exam. Nugent score $>4$ in the Gram-stained vaginal bacterioscopy was also used ${ }^{11-13}$.

\section{TREATMENTS}

After BV was diagnosed, oral metronidazole $500 \mathrm{mg}$ was administered bid during seven days. Furthermore, all BV remission-patients were instructed to proceed with genital hygiene consisting of a once-a-day topical rubbing of a small quantity (between 7.5 to $10 \mathrm{~mL}$ ) of a lactic acid plus lactoserum liquid soap, till foam is produced. Rinsing with abundant tap water was required after product administration. All subjects were instructed to avoid the use of genital deodorants, spermicides, female or male condoms, diaphragm, and tampons during the study. Compliance was checked trough clinical diaries. 


\section{EVALUATION PERIOD}

Each participant performed five visits: Visit 0 (admission) to confirm the BV diagnosis and to provide treatment with oral metronidazole; Visit 1 to confirm remission of BV and to initiate the use of a lactic acid plus lactoserum liquid soap (between day 8 and 12 after the end of the treatment with metronidazole). During visit 1 the cure of BV was evaluated with the same criteria used at the admission visit and remission was considered only if both clinical criteria and Nugent criteria were met. Three additional control visits (Visit 2, 3 and 4 at 30, 60 and 90 days \pm 5 , respectively) were scheduled after starting treatment with the soap.

Patients in whom BV remission was diagnosed were instructed to use a lactic acid plus lactoserum liquid soap for external intimate hygiene. In addition, vaginal content for the diagnosis of candidiasis was collected as well as vaginal $\mathrm{pH}$. Women with no disease remission at this visit were excluded from the study. During the visits 2 , 3 , and 4 the same procedures performed in visit 1 were carried out.

\section{Self-EVAluation QUESTIONNAIRE}

A self-evaluation questionnaire was developed for this study and it was applied in the form of visual analogue scale (VAS) in visits 1, 2, 3, and 4 after enrollment. The VAS scale is an instrument in which 0 (zero) represents that the subject was unsatisfied with the treatment and 10 fully satisfied. Applied questions were, as follows: 1) level of comfort in the genital region; 2) malodorous external genitalia; 3) comfort in sexual intercourse; 4) satisfaction or not regarding intimate hygiene; and 5) self-esteem.

\section{STATISTICAL ANALYSIS}

The sample size was established according to a 95\% confidence interval (CI) of BV recurrence with an accuracy of $10 \%$. A $40 \%$ BV recurrence rate was assumed and the number of subjects was set at 91 . Assuming 33\% lost-tofollow-up (LFU), we estimated a total enrollment of 122 women. The primary dependent efficacy variable was the rate of $\mathrm{BV}$ recurrence (laboratory diagnosis) measured during the three months of topical (genital region) hygiene with a lactic acid plus lactoserum liquid soap. The secondary dependent variable was the rate of vulvovaginal candidiasis measured during the three months of a lactic acid plus lactoserum liquid soap. Treatment was considered successful in case of no BV recurrence assessed during the three months follow up period.

The results of the five-question VAS self-applied questionnaire were presented as mean, median, range, and standard deviation (SD). The analysis included a paired $t$-test to compare values before and after treatment. The analysis of all the data follows the principle of intention to treat and data was presented as mean \pm SD and the level of significance was established at $\mathrm{p}<0.05$.

\section{RESULTS}

A total of 133 women were included in the study. Mean age was $32.0 \pm 7.2$, ranging from 18 to 50 year ; 67 women (54.5\%) were white; 31 (25.2\%) were black and 25 subjects (20.3\%) biracial. Body mass index (BMI; $\left.\mathrm{kg} / \mathrm{m}^{2}\right)$ was $26.5 \pm 5.4$ with a range of 16.8 to 41 . Contraceptive practices at baseline were reported by the patients as follows: 82 $(66.7 \%)$ were users of the copper intrauterine device (IUD, $62.6 \%)$ or of a levonorgestrel-releasing intrauterine system (LNG-IUS; 4.1\%), 12 (9.8\%) were users of male condom, $19(15.4 \%)$ of combined oral $(8.1 \%)$ or injectable contraceptives $(7.3 \%)$, and the other had undergone male or female sterilization. Only $13(10.6 \%)$ volunteers presented some clinical condition and the three most prevalent were blood hypertension, bronchitis and epilepsy.

At visit 0 (baseline) 123 patients were enrolled, 117 (95.1\%) presented vaginal discharge at the gynecological exam; vaginal $\mathrm{pH}>4.5$ was observed in 121 (98.4\%) of the patients, "clue cells" at the fresh exam in all the 123 patients, positive Whiff test in 119 (96.8\%) of the subjects, and Nugent score $>4$ in all the patients. Consequently, all the patients fulfilled at least three of the BV criteria for enrollment and all of them were instructed to initiate the oral metronidazole treatment.

At visit 1, after the end of the treatment with metronidazole, $100(81.3 \%)$ patients showed negative BV, 9 presented no remission and the other 14 were not evaluated due to LFU (12 women), one due to protocol violation, and the other because she did not wish to continue in the study. However, only 92 women initiated the treatment because 5 were LFU, two presented candidiasis and one experienced an adverse event.

At visit 2, 30 days after initiation of a lactic acid plus lactoserum liquid soap, 84 patients were available for evaluation because five women were discontinued due to candidiasis, two were discontinued due to protocol violation and one de to lost to follow-up. At visit 3, 60 days after initiation of a lactic acid plus lactoserum liquid soap, 62 patients were available for evaluation. The other 22 women were discontinued due to recurrence of BV (16), LFU (3), candidiasis (2), and one due to protocol violation. At visit 4, 90 days after the initiation of a lactic acid plus lactoserum liquid soap use, 42 patients were available for evaluation. The other 20 women were discontinued due to recurrence of BV (15), candidiasis (3), one due to LFU, and one due to protocol violation. Figure 1 shows the follow-up flowchart of the patients in the study. The rate of BV recurrence was 19.0, 24.2 and $7.1 \%$, respectively in the three visits (Table 1 ).

There were 11 adverse events associated with the use of the product under investigation in 9 women (9.8\%); vaginal candidiasis which occurred in 5 women $(5.4 \%)$ during the study treatment was the most common. The others were vulvar erithema, hyperemia, irritation and itching. 
Visit 1: 8-12 days after metronidazole

Enrolled: 123

Negative results for $\mathrm{BV}: 100$

No cure: 9

LFU*: 12

Protocol violation: 1

Removal of consent: 1

Visit 0: admission

Visit 2: $\mathbf{3 0}$ days

Evaluated: 62

Negative results for BV: 47

Visit 3: 60 days

Evaluated: 42

Negative results for BV: 39

Recurrence of $\mathrm{BV}: 15$

LFU*: 1

Candidiasis: 3

Protocol violation: 1

Visit 4: 90 days

Evaluated: 84

Negative results for BV: 68

Candidiasis: 5

Protocol violation: 2

LFU*: 1

Recurrence of $\mathrm{BV}: 16$

LFU*: 3

Candidiasis: 2

Protocol violation: 1

Initiated a lactic acid plus lactoserum liquid soap: 92

Candidiasis: 2

LFU*: 5

Adverse event: 1

Figure 1 - Follow-up flowchart of the patients in the study.

Table 1 - Recurrence of bacterial vaginosis throughout the study

\begin{tabular}{lccc}
\hline Visit & $\mathrm{n}$ & Yes & $95 \% \mathrm{Cl}$ \\
\hline V2 & 84 & $16(19.0 \%)$ & $10.6-27.4$ \\
V3 & 62 & $15(24.2 \%)$ & $13.9-35.3$ \\
V4 & 42 & $3(7.1 \%)$ & $0.0-15.1$ \\
Ever & 84 & $34(40.5 \%)$ & $30.0-51.0$
\end{tabular}

$\mathrm{Cl}$, confidence interval.
Regarding the evaluation of quality of life the data are shown in Table 2 . We only compared 42 women who completed the four visits scheduled for the entire study. Comparison between visit 1 (after remission with the use of metronidazol) and the last visit (visit 4) showed that among the 5 domains assessed all variables showed significant improvement at the end of the treatment.

\section{Discussion}

Oral or vaginal administration of metronidazol is the current, first-line and accepted treatment for $\mathrm{BV}^{4,5}$. Nevertheless, the high rate of remission is usually followed by high and unacceptable rates of recurrence $e^{6,7,14,15}$ even when metronidazol was prescribed at higher doses ${ }^{16}$. Albeit the natural history of BV was almost totally elucidated, complications such as pelvic inflammatory disease (PID), premature membrane rupture, premature birth, endometritis, and increased susceptibility to reproductive tract infections (RTIs) including HIV are the main concerns with $\mathrm{BV}^{17,18}$. In addition, the quality of life of women with $\mathrm{BV}$, mainly those with recurrent $\mathrm{BV}$, is hampered in many domains and in severely affected women it can lead to depression and adversely impact relationships; however, literature regarding quality of life of women with $\mathrm{BV}$ is scarce ${ }^{18}$.

The quality of life evaluated at the end of the treatment showed significant improvement in the five domains assessed. It is important to note that the level of comfort, the improvement in malodorous external genitalia, the comfort in sexual intercourse and the satisfaction with intimate hygiene were issues that could contribute to self-esteem which was also enhanced. In an Italian survey ${ }^{19,20}$, women and physicians reported that a more acid vaginal $\mathrm{pH}$ was associated to a more satisfactory sexual activity, more healthy genital conditions and considered that vaginal $\mathrm{pH}$ was an important aspect of everyday life. In general, the study's findings showed that appropriate intimate hygiene can be an important tool in women's everyday life. Our results were in accordance with these findings and the treatment can contribute to women's quality of life.

Our results showed that the use of a lactic acid plus lactoserum liquid soap, after laboratory confirmed BV remission, using the standard oral metronidazol treatment, was a good option to avoid BV recurrence. If we take into account that almost $70 \%$ of the cases of recurrence are reported up to 90 days after treatment with metronidazole ${ }^{6,7}$, our cumulative data of $50 \%$ recurrence with the use of a lactic acid plus lactoserum liquid soap confirm that this is a good option.

Recurrence of BV is a common problem in gynecological visits ${ }^{6,7}$ and a main concern for both patients and physicians. In a previous study ${ }^{12}$ with women with confirmed diagnosis and symptomatic BV, the recurrence 
Table 2 - Different domains of quality of life at the different visits

\begin{tabular}{lccc}
\hline Domain & Visit $2(\mathrm{n}=42)$ & Visit $5(\mathrm{n}=42)$ & $\mathrm{p}$-value \\
\hline Level of comfort & $8.1 \pm 1.9(3.0-10.0)$ & $9.2 \pm 1.1(5.8-10.0)$ & $<0.0001$ \\
Malodorous external genitalia & $8.5 \pm 1.9(3.5-10.0)$ & $9.4 \pm 1.1(4.0-10.0)$ & 0.0027 \\
Comfort in sexual intercourse & $8.1 \pm 2.4(0.5-10.0)$ & $9.3 \pm 0.8(7.2-10.0)$ & $=0.0003$ \\
Satisfied with the intimate hygiene & $8.4 \pm 2.1(1.5-10.0)$ & $9.3 \pm 1.3(2.6-10.0)$ & $=0.0003$ \\
Self-esteem & $8.5 \pm 1.9(1.0-10.0)$ & $9.4 \pm 0.7(6.8-10.0)$ & $<0.0015$ \\
Sum of the scores & $41.4 \pm 7.5(25.7-50.0)$ & $46.6 \pm 3.9(29.8-50.0)$ & $<0.0001$ \\
\hline
\end{tabular}

All values are mean $\pm \mathrm{SD}$ (range); * LFU, lost-to-follow-up.

of BV was $69 \%$ after remission with standard oral metronidazol through 12 months of follow-up. One of the strength of that study was a $94 \%$ follow-up with at least one control. The identified variables associated to recurrence were past history of $\mathrm{BV}$, regular sex partner throughout the study and female sex partners ${ }^{14}$. The main confounding variable was the fact that a regular partner was associated to recurrence of $\mathrm{BV}$ when a previous study showed that new partners are a risk factor for recurrence $^{18}$.

One of the problems with BV is that there are no clear recommendations to avoid or to treat recurrence and it was stated that $500 \mathrm{mg}$ of oral metronidazole bid for 7 days should be the first option due to the high remission rates ${ }^{19}$, albeit $\mathrm{CDC}^{20}$ and $\mathrm{UK}$ guidelines ${ }^{21}$ do not report evidence of such treatment results. In addition, treatment with metronidazole gel or placebo did not show benefits of the drug in the 28-week follow-up ${ }^{22}$.

Moreover, it was observed that secondary vaginal candidiasis occurred significantly more often in the group of women treated with metronidazole ${ }^{22}$; however, although vaginal candidiasis was the most common sideeffect observed in our study it only accounted for almost $6 \%$ of the patients treated with a lactic acid plus lactoserum liquid soap.

Although vaginal acidification has recently been studied, the results have been disappointing and the use of acetic acid gel was ineffective in the treatment of $\mathrm{BV}^{23,24}$. However, recently, in a Philippine study ${ }^{25}$, a product similar to the experimental one in this study was used. This was a three arm-study; one with metronidazole; one with lactic acid gel in an intravaginal administration and the other arm with a combination of both drugs. The administration of intravaginal lactic gel offered better results than the other two treatments regarding the growth of lactobacilli colonies, and metronidazole with lactic acid gel caused a significant reduction of malodorous vaginal discharge (Whiff test) and the lowest recurrence of BV.

Nevertheless, the significant decrease in the $\mathrm{pH}$ level and frequency of "clue cell" positive patients was not significantly different between the three treatment groups. In addition, the main limitation of that study was that the follow-up period was only up to 56 days and the participants were not individualized as remission or persistence of $\mathrm{BV}^{25}$. In addition, we need to take into account that it was established ${ }^{26}$ that the possibility of changing Nugent score every 6 or 12 months was normally distributed.

Our study showed that the use of a lactic acid plus lactoserum liquid soap, after standard treatment with metronidazole for $\mathrm{BV}$ was able to control the recurrence of the infection and this had an impact on the improvement of quality of life, a neglected aspect of BV women's life.

One criticism could be that almost $67 \%$ of the women assessed were users of a copper IUD or an LNG-IUS and it was described that among new users of IUD the prevalence of BV was $19.7 \% \%^{27}$. Nevertheless, our own previous results ${ }^{25}$ showed that BV after one month of IUD insertion was not associated with IUD complications, with the exception of dysmenorrhea, and there are no reports that users of IUD are more prone to recurrence of BV after appropriate treatment. However, our study has some limitations indeed. The study was non-blinded, we did not deploy an untreated control group which could provide more accurate information about the treatment group and the follow-up was only up to 90 days after beginning the treatment. Consequently, we cannot anticipate what the results will be in the long-term follow-up.

Although further studies are required in order to recommend the use of a lactic acid plus lactoserum liquid soap as a treatment against BV recurrence, our results showed that the use of a lactic acid plus lactoserum liquid soap is a good option for the prevention of BV recurrence after treatment and cure with metronidazole, specially if we take into account the lack of other positive treatments for BV recurrence and considering that intimate hygiene was described as a tool for BV treatment or prevention ${ }^{28}$. The prevention of $\mathrm{BV}$ recurrence probably requires several treatment modalities and the findings of our study can help women with $\mathrm{BV}$ and could help in the reduction of BV associated complications as well as improve quality of life.

\section{AcKNoWledgements}

This study was financed by an unrestricted grant by Sanofi-aventis, São Paulo, Brazil. 


\section{References}

1. Hillier S, Holmes KK. Bacterial vaginosis. In: Holmes KK, Mardh PA, Sparling PF, Lemon SM, Stamm WE, Piot P et al., editors. Sexually transmitted diseases. $3^{\text {rd }}$ ed. New York: McGraw-Hill; 1999. p.563-86.

2. Spiegel CA. Gardnerella vaginalis and Mobiluncus Species. In: Mandell GL, Bennett JE, Dolin R, editors. Principles and practice of infectious diseases. $5^{\text {th }}$ Philadelphia: Churchill Livingstone; 2000. v.2, p. 2383-6.

3. Martin HL, Richardson BA, Nyange PM, Lavreys L, Hiller SL, Chohan B et al. Vaginal lactobacilli, microbial flora, and risk of human immunodeficiency virus type 1 and sexually transmitted disease acquisition. J Infect Dis 1999;180:1863-8.

4. Centers for Disease Control and Prevention. 1998 Guidelines for treatment of sexually transmitted diseases. MMWR Morb Mortal Wkly Rep 1998;47(RR-1):70-9.

5. Livengood CH, Soper DE, Sheehan KL, Fenner DE, Martens MG, Nelson AL et al. Comparison of once-daily and twice-daily dosing of $0.75 \%$ metronidazole gel in the treatment of bacterial vaginosis. Sex Transm Dis 1999;26:137-42.

6. Sobel JD, Schmitt C, Meriwether C. Long-term follow-up of patients with bacterial vaginosis treated with oral metronidazole and topical clindamycin. J Infect Dis 1993;167:783-4.

7. Boris J, Pahlson C, Larsson PG. Six years observation after successful treatment of bacterial vaginosis. Infect Dis Obstet Gynecol 1997;5:297-302.

8. Ferris DG, Francis SL, Dickman ED, Miler-Miles K, Waller JL, McClendon N. Variability of vaginal $\mathrm{pH}$ determination by patients and clinicians. J Am Board Fam Med 2006;19:368-73.

9. Soper DE. Gynecologic complications of bacterial vaginosis: fact or fiction? Curr Infect Dis Rep 1999;1:393-7.

10. Andersch B, Forssman L, Lincoln K, Torstensson P. Treatment of bacterial vaginosis with an acid cream: a comparison between the effect of lactate-gel and metronidazole. Gynecol Obstet Invest 1986;21:19-25.

11. Simoes JA, Discacciati MG, Brolazo EM, Portugal PM, Dini DV, Dantas MC. Clinical diagnosis of bacterial vaginosis. Int J Gynaecol Obstet 2006;94:28-32.

12. Amsel R, Totten PA, Spiegel CA, Chen KCS, Eschenbach D, Holmes KK. Non-specific vaginitis. Diagnostic criteria and microbial and epidemiological associations. Am J Med 1983;74:14-22.

13. Nugent RP, Krohn MA, Hillier SL. Reliability of diagnosing bacterial vaginosis is improved by a standardized method of gram stain interpretation. J Clin Microbiol 1991;29:297-301.

14. Bradshaw CS, Morton AN, Hocking J, Garland SM, Morris MB, Moss LM et al. High recurrence rates of bacterial vaginosis over the course of 12 months after oral metronidazole therapy and factors associated with recurrence. J Infect Dis 2006;193:1478-86.
15. Bradshaw CS, Tabrizi SN, Fairley CK, Morton AN, Rudland E, Garland SM. The association of Atopobium vaginae and Gardnerella vaginalis with bacterial vaginosis and recurrence after oral metronidazole therapy. J Infect Dis 2006;194:828-36.

16. Gray RH, Wabwire-Mangen F, Kigozi G, Serwadda D, Moulton LH, Quinn TC et al. Randomized trial of presumptive sexually transmitted disease therapy during pregnancy in Rakai, Uganda. Am J Obstet Gynecol 2001;185:1209-17.

17. Camargo RP, Simões JA, Cecatti JG, Alves VM, Faro S. Impact of treatment for bacterial vaginosis on prematurity among Brazilian pregnant women: a retrospective cohort study. São Paulo Med J 2005;123:108-12.

18. Hay P. Recurrent bacterial vaginosis. Curr Opin Infect Dis 2009; 22:82-6.

19. Alfonsi GA, Shlay JC, Parker S, Neher JO. What is the best approach for managing recurrent bacterial vaginosis? J Fam Pract 2004;53:650-2.

20. CDC Sexually Transmitted Disease Treatment Guidelines 2006. MMWR Morb Mortal Wkly Rep 2006;55:50-2.

21. Clinical Effectiveness Group British Association for Sexual Health and HIV. National Guideline for the Management of Bacterial Vaginosis; 2006. [cited 2009 oct. 22. Available from:http://www.guideline.gov.

22. Sobel JD, Ferris D, Schwebke J, Nyirjesy P, Wiesenfeld HC, Peipert $\mathrm{J}$ et al. Suppressive antibacterial therapy with $0.75 \%$ metronidazole vaginal gel to prevent recurrent bacterial vaginosis. Am J Obstet Gynecol 2006;194:1283-9.

23. Holley RL, Richter HE, Varner RE, Pair L, Schwebke JR. A randomized, double-blind clinical trial of vaginal acidification versus placebo for the treatment of symptomatic bacterial vaginosis. Sex Transm Dis 2004;31:236-8.

24. Boeke AJ, Dekker JH, van Eijk JT, Kostense PJ, Bezemer PD. Effect of lactic acid suppositories compared with oral metronidazole and placebo in bacterial vaginosis: a randomized clinical trial. Genitourin Med 1993;69:388-92.

25. Decena DCD, Co JT, Manalastas RM, Palaypayon EP, Padolina CS, Sison JM et al. Metronidazole with Lactacyd vaginal gel in bacterial vaginosis. J Obstet Gynaecol Res 2006;32:243-51.

26. Ness RB, Kip KE, Soper DE, Stamm CA, Rice P, Richter HE. Variability of bacterial vaginosis over 6 to 12-month intervals. Sex Transm Dis 2006;33:381-5.

27. Ferraz do Lago R, Simões JA, Bahamondes L, Camargo RP, Perrotti $\mathrm{M}$, Monteiro I. Follow-up of users of intrauterine device with and without bacterial vaginosis and other cervicovaginal infections. Contraception 2003;68:105-9.

28. Guaschino S, Benvenuti C; SOPHY Study Group. SOPHY project: an observational study of vaginal $\mathrm{pH}$, lifestyle and correct intimate hygiene in women of different ages and in different physiopathological conditions. Part II. Minerva Ginecol 2008;60:353-62. 